\title{
DÉFICIT PÚBLICO E TAXA DE JUROS
}

Fernando J. Cardim de Carvalho ${ }^{1}$

1. Hipótese subjacente é a de que taxa de juros é elevada porque o déficit corrente é elevado e espera-se que permaneça elevado. Com isso, espera-se que a oferta de títulos públicos mantenha-se elevada, fazendo com que seu preço caia e a taxa de juros suba. A eliminação do déficit eliminaria o excesso de oferta de títulos públicos, levando a uma redução da taxa de juros. A taxa de juros seria elevada porque o mercado julgaria o governo falido.

2. Em circunstâncias normais, a taxa de juros de curto prazo seria determinada pela política monetária, fixando o preço das reservas bancárias, e as taxas de juros de médio e longo prazo, pela oferta e demanda de papéis, conformando uma curva de rendimentos. No Brasil, porém, não há uma curva de rendimentos, pela inexistência de um segmento de médio e longo prazo no mercado de títulos. O predomínio de papéis indexados à taxa Selic torna a curva de rendimentos limitada ao segmento curto do mercado. A maturidade formal dos papéis importa apenas quando há risco político (o risco de uma decisão de governo pelo default, como o esperado pelo mercado em 2002 para papéis com vencimento em 2003, no caso de vitória do PT nas eleições presidenciais).

3. Deste modo, a taxa de juros de curto prazo é determinada pelo Banco Central, de acordo com os objetivos de política monetária, como os de atração de capitais externos, na primeira fase do Plano Real, ou de defesa de metas inflacionárias, no período pós-1998. No entanto, não há taxas de médio e longo prazo porque não há demanda para papéis de maturidades mais longas a taxas de juros pré-fixadas. Quando há a expectativa de redução da taxa Selic, cresce a demanda por papéis relativamente mais longos, para lock in a taxa corrente de juros, mas mesmo então o prazo é relativamente curto.

4. A razão para a inexistência de demanda por papéis mais longos parece ser a exposta por Keynes, a incerteza a respeito das taxas de juros no futuro. Desde 1994, o uso mais agressivo da política monetária, seja para garantir o desempenho da conta de capitais do balanço de pagamentos, seja para atingir metas inflacionárias, não apenas tornou as

\footnotetext{
${ }^{1}$ Professor do Instituto de economia da Universidade Federal do Rio de Janeiro (IE-UFRJ). Endereço eletrônico: fjccarvalho@uol.com.br.
} 
expectativas de juros voláteis, mais sinalizou a possibilidade de repetição no futuro de episódios em que a taxa de juros é elevada a níveis extremamente elevados. O risco de perdas de capital embutido no emprego de políticas monetárias agressivas se refletiria, em termos de uma curva de rendimentos, em taxas de médio e longo prazos extremamente elevadas, ou seja, o mark up sobre as taxas de curto prazo seria muito alto, para cobrir o risco de que essas taxas fossem superadas por altas agudas de taxas de juros no futuro. A alternativa a esse nível de juros é a indexação dos papéis de maior maturidade à taxa de juros de curto prazo, eliminando o risco de capital.

5. A eliminação do déficit público em período relativamente curto não mudaria as expectativas com relação à possibilidade de altas descontínuas de juros, e, assim, não há porque esperar que as taxas de juros correntes sobre um segmento (a ser criado) de papéis de prazo mais longo (o trecho da curva de rendimentos correspondente às taxas de juros de médio e longo prazo) fossem fixadas pelo mercado a níveis compatíveis com as possibilidades de financiamento da atividade produtiva e de investimento no Brasil. Apenas se a inflação brasileira fosse causada por excesso de demanda agregada (e que, além disso, a taxa de juros não fosse mais usada, como no passado recente, para controlar episódios de fuga de capitais) é que se poderia esperar que a autoridade monetária não fosse mais levada a aumentar drasticamente a taxa de juros de curto prazo, possibilidade que sustenta a configuração peculiar do mercado brasileiro de papéis públicos.

6. Adicionalmente, em artigo no Valor de 26/07/2005, o Professor Delfim Netto, discutindo sua proposta de eliminação do déficit público corrente observou que "o programa parte das seguintes hipóteses: i). os agentes antecipação a queda dos juros, e a natureza da dívida se alterará em favor de papéis pré-fixados, com prazos maiores e taxas de juros menores; ii). a profissionalização absoluta da administração pública, com um 'choque de gestão', um congelamento das despesas reais de custeio durante o prazo do programa e um aprofundamento das privatizações; iii). um olhar severo sobre as 'vinculações' (a mãe dos desperdícios) e sobre a seguridade social oferecerá, pelo aumento da produtividade, mais educação e saúde do que hoje; e iv). uma ampliação forte da concorrência interna e uma redução tarifária para facilitar as importações, tudo combinado, reativarão os investimentos e o crescimento, reduzindo ainda mais depressa a dívida/PIB e a taxa de juros real."

7. As razões para questionar o otimismo da primeira hipótese já foram apontadas.

8. A segunda hipótese, sobre o 'choque de gestão', pode ser igualmente otimista. A redução drástica de despesas já vem sendo praticada com a fixação (e costumeira 
ultrapassagem) das metas de superávit primário, sem que haja qualquer evidência de que o ajuste à maior escassez de recursos tenha sido diferente do racionamento da oferta de serviços públicos, pura e simples, seja através da redução do volume de serviços, seja através da deterioração da sua qualidade. Promover um 'choque de gestão' deveria ser um objetivo de governo, independentemente de quaisquer outros fatores, mas é duvidoso que um corte ainda maior de recursos, por si mesmo, leve a isso.

9. Em tese, a desvinculação de receitas, no futuro, seria o ideal, permitindo à sociedade fazer suas escolhas a cada momento, de acordo com seus objetivos e prioridades. A existência de vinculações é, em si, indicação de desconfiança na capacidade das instituições políticas de refletir esses objetivos e prioridades em sua atuação na fixação do orçamento de despesas. Os eventos correntes certamente não contribuem para aumentar a confiança na capacidade dessas mesmas instituições agirem de forma adequada. Nessas circunstâncias, as vinculações funcionam como um "seguro" contra o uso ilegítimo dos recursos públicos, e sua eliminação dificilmente seria politicamente aceitável ou mesmo recomendável.

10. A ampliação da concorrência e o estimulo ao investimento são, naturalmente instrumentos importantes de promoção da retomada do desenvolvimento, mas sua relação com o déficit público corrente é, no máximo, tênue.

11. A racionalização das receitas e despesas públicas, eliminando-se vinculações e outros artifícios, deve ser um objetivo de longo prazo. A separação entre um orçamento de custeio, cobrindo as funções permanentes e essenciais do Estado, para o qual recursos suficientes devem ser assegurados de forma igualmente permanente, e um orçamento de capital, discricionário, que possa ser implementado de forma anticíclica, contribuiria para isto. Nas condições presentes, no entanto, esse objetivo não parece possível, nem desejável. 


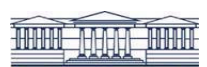

UFPR 